\title{
POLITICAL WILL AND THE ROLE OF THE PEOPLE: FIGHTING CORRUPTION IN UKRAINE AFTER THE REVOLUTION
}

\author{
Irina B. Olimpieva \\ $\mathrm{PhD}$ (Candidate of Science), Senior Researcher at the Center \\ for Independent Social Research (SPb), Coordinator \\ of the Research Department "Social Studies of the Economy". \\ E-mail: olimp@cisr.ru; irinaolimp@gmail.com

\section{Robert Orttung} \\ $\mathrm{PhD}$, Research Director of the GW Sustainability Collaborative \\ and Associate Research Professor of International Affairs, \\ George Washington University. \\ E-mail: rorttung@gmail.com
}

"It looks like we have elected the wrong people..." Focus group participant

\begin{abstract}
The article analyzes the concept of political will and the role of the population in the battle with high-level corruption in post-communist Ukraine. We start with the assertion that political will in the battle with corruption is derivative of the character of the interaction between the population and the state, and in particular, to what extent the population adopts a "patron-orientation" to the political leadership of the country and holds them accountable. Accordingly, to analyze the strength and dynamics of political will, we suggest researching the way in which the population views the authorities rather than the personality of political leaders. We use a multi-disciplinary approach for understanding political will by proposing to look at it as a combination of political "want", "can", and "must" in the battle with corruption. In the methodological part of the paper, we examine quantitative and qualitative approaches to studying political will. We lay out an empirical analysis based on 14 focus groups which were conducted with representatives of various social layers of the population in four Ukrainian cities in May 2015. Analyzing the narratives makes it possible to define empirical indicators, which can be used for researching political will, particularly the age and regional distribution of the participants in the focus groups.
\end{abstract}

Keywords: political will; corruption; patron-client relationships; political role of the population; Euromaidan revolution.

Citation: Olimpieva, I.B. \& Orttung, R. (2016). Political Will and the Role of the People: Fighting Corruption in Ukraine after the Revolution. Public Administration Issues, no 5 (Special Issue, electronic edition), pp. 60-76 (in English). 


\section{Introduction}

In Ukraine, corruption has become a systemic feature of society ${ }^{1}$, reducing economic growth, undermining democratic institutions, and weakening the provision of security. Comparative indexes of corruption prepared by Transparency International, the World Bank, and other international organizations consistently show Ukraine to be the most corrupt country in Europe and among the most corrupt countries in the world. Extensive anti-corruption campaigns encouraged by the leading international political and financial institutions have so far not led to substantial progress, according to recent polls of the Ukrainian population ${ }^{2}$.

The relatively small amount of success in fighting corruption in Ukraine is often attributed to the "lack of political will"3. For example, Transparency International-Ukraine (TI) noted in its report on the period from October 2014 to May 2015 that "Ukraine has achieved notable progress in reforming anti-corruption legislation, but on the other hand there is lack of political will from the Cabinet of Ministers, the President and the Verkhovna Rada to implement the new laws". Similarly, Taras Kuzio declares that "there is a near total absence of political will among Ukrainian politicians to seriously combat corruption (Kuzio, 2015, p. 326)." The presence of political will can also be used to explain reform success where there is more visible progress than in Ukraine. According to the World Bank analysis, Georgian President Mikheil Saakashvili was uniquely successful in Georgia because of his "strong political commitment, backed by the comprehensiveness, pace, boldness, and sequencing of the reforms and, most important, the strong role of the executive in implementing them (World Bank, 2012, p. 11)." Working within this framework, observers often point out that asserting the right kind of political will for the situation is crucial. As investigative journalist turned member of parliament, Mustafa Nayyem, points out, "It is important that this [political] will appear before the people, out of despair, seek to bring a Ukrainian Pinochet to power"s. For Ukraine, political will is the missing element in the traditional anti-corruption triangle - strong political will, mobilized civil society, and independent mass media. Even though it is widely recognized that Ukraine currently has a strong civil society and a developed independent media, the country is not able to successfully fight corruption in the absence of strong political will.

\footnotetext{
Corruption is a multifaceted problem with political, economic, social, and cultural aspects. In this article, we examine mainly high-level corruption, affecting the economic and political systems of Ukraine and is manifested in the kleptocracy, theft of state resources and the actions of the oligarchs. Experts see these problems as the main barriers to the economic development of the country.

2 See, for example, Andriy Bychenko, "Ukrainians Lost Confidence in the Authorities and Increasingly Rely Only on Themselves," Razumkov Centre Newsletter, no 24, October 9, 2015, http://razumkov.org.ua/ upload/Newsletter_24_en.pdf

3 Although the notion "political will" could be used to analyze any kind of reforming process (general economic and political reforms or implementation of reforms in some particular areas like energy, education, medicine, pensions, etc.), in this paper while using the term "political will" we mean political will to fight corruption and to implement anti-corruption reforms.

4 http://ti-ukraine.org/en/news/oficial/5426.html

5 Mustafa Nayyem post on Facebook, September 17, 2015, https://www.facebook.com/Mustafanayyem/ posts/10205281260217085
} 
Despite the recognized importance of political will for effectively fighting corruption, the concept is poorly developed both in political science and in practical managerial applications. Frequently, the phenomenon of will is viewed from a psychological perspective and is conceived as the leadership ability and personal motivation (or internally driven initiative) of specific politicians ${ }^{6}$. At the other extreme, political will is seen as the entire complex of individual, organizational, and institutional elements of the system of state management (e.g., Brinkerhoff 1999). Most often, however, the term "political will" is used without any explanation, as a term that presumably makes sense in and of itself. Typically, political will is seen as some sort of impulse for anti-corruption reforms coming from the supreme echelons of authority, the head of state, or the political establishment. Given these wide interpretations, the term leaves numerous questions unanswered: What is the nature of political will as a key anti-corruption tool? What are the sources and drivers of political will? To what extent are they able to strengthen or weaken the realization of anti-corruption reforms? Is it possible to measure political will? Can you influence it?

In this article, we try to answer these questions from a multi-disciplinary perspective. We base our analysis on the assertion that in the post-communist, neopatrimonial states, the main (and often only) drivers of political will are external, not internal, coming from society rather than the individual motivations of a particular political leader or from the institutional capacity of the state. Therefore, to define the concept of political will in the battle against corruption, it is necessary to place the idea of political will within the broader context of society (Migdal, 2001). Our argument is based on the thesis that strong political will asserted by the authorities is the result of a high level of political will within the population, which is able to monitor and hold their authorities accountable in implementing a set of anti-corruption reforms.

The article begins with an analysis of the various approaches to understanding political will. We show that existing approaches undervalue the role of society in the formation of political will. Building on the institutional conception of political will proposed by political scientists (Persson \& Sjöstedt, 2012), and the practically oriented governance approach proposed by Malena (2009), we see the political will of the authorities in implementing anti-corruption reforms as derivative of (or a mirror reflection of) the political will of the population. From this perspective, the political will of the population is not only and exclusively through the activity of civil society organizations and the strength of direct political pressure on the authorities, but also in the character of the way that society perceives its authorities' political position, in the recognition of their own ability to influence the authorities, and in the implementation of anti-corruption reforms. In this context, the most important type of empirical research regarding political will focuses on society and the population rather than the political establishment and NGOs.

The methodological part of the article operationalizes the concept of political will. It examines the opportunities for quantitative and qualitative approaches to researching the given phenomenon. We propose an analytical framework for

For a discussion on political will as individual-level concept see Post, Raile and Raile, 2010, p. 656. 
the further development of instruments for quantitative research and also examine the opportunities for qualitative research of political will. In this article, we focus on developing the qualitative analysis. Our qualitative work is based on 14 focus groups conducted with representatives of various social groups from the populations of four Ukranian cities in the spring of 2015. In the concluding section, we discuss the theoretical contribution of this approach for empirical research examining the phenomenon of political will in the battle with corruption and analyze its methodological possibilities and limitations.

\section{Political Will: Definitions and Approaches}

As we noted above, the concept of political will is extremely popular in explaining the success or failure of anti-corruption reforms. Defining political will as the internal motivation of a political leader, combining psychological qualities and individual interests, limits the explanatory potential of the concept of political will particularly in analyzing the anti-corruption reforms undertaken in the aftermath of colored revolutions in post-communist countries.

Post-revolutionary politicians do not automatically have the motivation to fight corruption, for the simple reason that politicians who are supposed to implement anti-corruption reforms in post-communist states are often personally involved in oligarchic networks and pursue their own private interests which do not necessarily match an anti-corruption agenda (Bueno de Mesquita, Smith, Siverson, \& Morrow, 2003). As institutional scholars have pointed out, it does not make sense to rely on the charitable inclinations of politicians to carry out necessary reforms (Hale, 2016). The anti-corruption effort to reform state governance which started in Ukraine after the Euromaidan revolution is a good illustration for this statement. Despite the fact that President Petro Poroshenko came to power in the wake of a popular uprising aimed largely at replacing the previous political system with a vaguely defined "European" alternative, his political will to fight corruption is limited by his own personal financial and institutional interests. At the same time, he has laid out a variety of reforms and many institutional changes are being implemented. Under such conditions, one can assume that the contradictory character of the political will of the current political leadership in Ukraine is caused by the clash of public-driven versus politically and individually driven incentives and pressures. On the one hand, there are expectations on the part of the general public that provided Poroshenko with a mandate of trust in the post-Maidan elections, on the other hand, entrenched interests (or perhaps just a lack of interest in exerting the enormous effort required to develop and implement reforms) that can block reforms remain in place.

Another disadvantage of the individualistic approach is that it is hard to measure political will when it is defined in such black box leadership terms. An effective approach to measuring political will seeks to better take into account the motivations for leadership behavior and the context within which the leaders operate. Scholars working on the sub-Saharan African countries have developed such a theory (Persson \& Sjöstedt, 2012). At the micro-level, Persson and Sjostedt advocate using a principal-agent theory. Under this framework, a country's popu- 
lation represents the principal and the elected politicians are their agents. Rather than seeing political will as a "black box," this theory Posits that the behavior of leaders is guided by the opportunity and incentive structure they face, and that this opportunity and incentive structure should, in turn, be expected to vary considerably depending on the degree to which the citizens are willing and able to control the leaders. In societies in which citizens take on the role of being a "principled principal," leaders should be expected to have fewer opportunities and incentives to act opportunistically compared to societies in which the citizens are not willing or able to take on such a role (Persson \& Sjöstedt, 2012). (emphasis added)

In other words, the degree to which citizens are willing to exercise their citizenship rights to form associations and individually exert oversights of their leaders determines to what extent the leaders are able to engage in high level corruption. The political will to address corruption then is a function of public efforts. Robert Johnston came to a similar conclusion with his argument that "lasting corruption control requires deep democratization - not building democracy in an electoral or constitutional sense, but rather enabling and encouraging citizens to check abuses of wealth and power through political advocacy of their own interests (Johnston, 2014, p. xii)"”

Persson and Sjostedt's article makes a real contribution because the authors argue that political will is not just voluntaristic leadership behavior, but depends on the characteristics of the society, and in particular, the legitimacy of the state, namely, the state in people's perceptions.

This focus on society takes us farther than methodologies that emphasize the state. For example, international organizations, such as Transparency International and the World Bank, which are actively involved in anti-corruption campaigns in post-Soviet states, are more interested in the effectiveness of implementing anticorruption reforms and state management in general. From a governance point of view, PW is closely connected with implementation capacity, "and what may look to outsiders as a lack of political will to advance certain reforms may actually be a symptom of insufficient government capacity" (TI Guide, p. 6). The main problem is seen as the lack of certainty and resources to implement reforms. From this point of view, even politicians with good intentions to implement reforms would not try to do this because they are not sure that they possess enough resources and support from "all stakeholders" for this complicated enterprise. From the governance logic, in order to strengthen political will, it is important to mobilize stakeholders' support and organizational/institutional resources.

In further developing the concept of political will, the views on the nature of political will proposed by (Malena, 2009) in her research on participatory governance are useful. She disaggregated the concept into three elements, defining political will as the sum of "political want," "political can" and "political must." Further developing this construct with regard to the battle against corruption, we can suggest that "political want" to undertake a given action is essentially political motivation, "political can” represents capacity (organizational, institutional, etc.) to undertake that action, and "political must" implies some compulsion to undertake this action. We argue that in a neopatrimonial state, such as Ukraine, the main active element for political will in the battle with corruption is "political 
must," which is activated exclusively under external pressure. An important source of pressure comes from international organizations, but a stable, long-term effect is possible only when society is exerting the pressure. Thus, to research the level and dynamics of political will it is necessary to focus not on the psychological qualities of political leaders, but on society, and in particular, the mutual relationship between society and the state.

\section{Political Will: Public Perspective}

Our analysis draws on the traditional argument that successful anti-corruption reform is based on the presence and interaction of three crucial elements: strong political will, mobilized civil society, and independent mass media. However, we argue that another important element, which is missing here, is the general public. Common people usually attract researchers' attention during revolutions and studies focus on the role of mass protests in the revolutionary change of political regimes (Onuch, 2014; Zelinska, 2015). However, after the revolution, when it comes to the implementation of reforms, the focus of analysis usually shifts to state institutions, civil society organizations and the role of social players such as the media. Although public participation is seen by scholars as a critical condition of building trustworthy states in transforming societies (Rose-Ackerman, 2004), this concept has never been applied to the analysis of political will.

Civil society is supposed to play the role of intermediary between the state and individual citizens (Greene, 2014). However, previous research shows that the link between civil society organizations and the general public is still problematic in Ukraine, which makes the situation look similar to the aftermath of the Orange revolution. NGOs often live in their own world, obtaining financing from Western and other donors, but often lacking strong connections to members of the public. Some have described this situation as "NGOcracy" (Lutsevych, 2013, p. 4).

In this paper, we will look at the political will to fight corruption and implement reforms in Ukraine from the people's perspective. Political will does not work without popular support and pressure on the country's top politicians, who must define and implement policy. We proceed from the assumption that the state of the population's political will and its dynamics serve as an indicator of the level and changes in the political will of the authorities in the battle with corruption. Following the patron-client model proposed by Persson and Sjostedt, we can say that the more that the population sees itself as the "patron" (and not the client), namely that it is the one that holds power, the greater the political will for carrying out reforms. Using the patron-client analytical frame is necessary to emphasize the vector of power relations - in the citizen-politician duo, the citizen should hold a position of power in relation to elected politicians. The category of political will reflects the extent to which the population understands this power position.

In this way, we study political will in combatting corruption by examining the extent to which the population sees itself as a patron in its relationship with the authorities. Understandably, the most obvious expressions of the population's political will are political actions, protests, and the like which work through the instrument of direct political pressure. Despite all their importance, protests 
in neopatrimonial states do not always reflect the real state of social consciousness. The participation of simple citizens in protests presupposes many cultural, historical, social, and political factors. Changes in the way that the population understands political institutions or states do not always find immediate expression in the form of political actions. Therefore, to analyze the political will of the population (in realizing anti-corruption reforms) it is important to research a society's dominant relationship with its political institutions and politicians and the understanding of citizens of themselves as subjects in political relations. The character of the population's attitudes toward the authorities does not exert direct political pressure, but in the final analysis sets the level of institutional expectations from society in relation to the existing authorities; these expectations are no less important a factor of political influence than political protests and actions.

\section{Measuring Political Will: Quantitative and Qualitative Approaches}

Researching political will according to the methods proposed above can proceed with both quantitative and qualitative approaches. Here we lay out a guide for a quantitative approach, but the rest of the article focuses on a qualitative analysis.

The quantitative approach is useful if the researcher seeks to measure the level and dynamics of political will. Quantitative research answers the question of how strong the pressure from society on politicians is in forcing them to take steps in implementing anti-corruption reforms. To empirically measure this aspect, we suggest disaggregating the concept of political will into its component elements in order to operationalize it and develop a system of indicators for empirical measurement. Analogous to the approach proposed by Malena, we represent the concept of political will of the population as the sum of political want, political can, and political must:

- Political want denotes the presence among people of a desire to influence policy and monitor the activity of political institutions. A patron-oriented consciousness denotes a high level of interest in conducting reforms, being informed about the course of the reforms (including actively seeking out information), and a willingness to participate in the processes of their implementation. In contrast to a patron-oriented position is a client position, which is characterized by the absence of political interest, a low and passive level of being informed, and a dominating desire to receive something from the state and elected officials - analogous to the electorate of a clientelistic party (Hale, 2014).

- Political can denotes recognition of the ability to monitor the activity of the political establishment, including an effort to replace elected officials, if they do not answer the desires of the population, do not implement their campaign promises, and do not conduct the necessary anti-corruption reforms. A patron-oriented position along this parameter expresses a high level of confidence in their ability to influence the authorities and the effectiveness of the work of the democratic institutions and instruments of accountability. A client position appears in one's recognition of one's own political powerlessness and inability to influence the authorities in adopting decisions and conducting reforms. 
- Political must is recognition of one's civic responsibility, viewing oneself as a part of society, which is a political subject, wielding power, and not an object of political manipulations. A patron-oriented position in this parameter is expressed in recognizing the necessity of holding elected officials accountable. An important condition of political must is trust in political institutions and the state, which is expressed by actively participating in political elections.

Following this procedure of disaggregation, researchers can evaluate weak and strong aspects of political will, trace the dynamics of specific parameters, and compare aggregate and individual indicators of political will in regional units and in various social groups. This analytical scheme is a first step on the path to developing an instrument for quantitative research. The choice of empirical indicators, the format of the questionnaire, the specific questions asked, and the measurement scales used to define the further development of the survey methodology.

In contrast to the quantitative approach, which seeks to measure the strength and dynamics of political will, the qualitative approach is designed to answer the question of how political will is constructed, which factors influence its change, and which manifestations of political will it is possible to find in the narratives of ordinary citizens. In such qualitative research, the guides for conducting interviews or focus groups should be directed toward ascertaining the character of how citizens understand their positions as political actors - the desire, ability and need to influence the political authorities, in particular, in their effectiveness in realizing anti-corruption reforms. In contrast to quantitative surveys, where the system of empirical indicators and factors is defined at the stage of developing the survey instrument, in qualitative research, the definition of these indicators from the views of the citizens themselves is effectively the final result of the analysis. As an example of this type of qualitative research for analyzing political will, we look at the empirical data collected in the course of field research in Ukraine.

\section{Public Views: Analysis of Focus-Group Discussions}

In this section, we will analyze the transcripts of 14 focus-group discussions that were conducted in April/May 2015 within the framework of an USAID project on everyday corruption in Ukraine. The focus groups were held in three large Ukrainian cities (Kyiv, Kharkiv and L'viv) and the small town of Korostyshev in Zhitomir region. In each city, focus groups brought together men and women of different ages representing different socio-professional groups. The focus group participants did not work in NGOs, for the government, or in journalism and they were not political party activists. Although these focus groups were not purposely designed to reveal the participants' desire, capability or necessity to influence elected politicians, this material can be (at least partially) used for the purposes of our study. During the discussions people expressed their attitudes towards the new political leadership and assessed the changes in the country's development after Euromaidan. Some of these narrations demonstrate people's perceptions of themselves as political actors and can serve for the qualitative analysis of how political will is constructed and manifested in people's minds. By analyzing focus group discussions, we do not mean to measure political will in Ukraine today, but to find 
some manifestations or indicators of how people in Ukraine position themselves as political actors, how they assess the changes (if any) in the economy and, most importantly, in their society after Euromaidan. An additional task is to determine what criteria people use when evaluating the performance of political leaders and their ability to fight corruption.

The focus groups produced considerable interesting material characterizing the overall situation in the country, the way that the population views politicians, and evaluation of the level of corruption, among other things. In this section, we highlight only those aspects which characterize, directly or indirectly, the positions of the respondents as political actors. Specifically, this is trust in the state and in elected politicians as a necessary prerequisite for political will, the character of assessments of the changes in the economy and society after the Euromaidan revolution, and attitudes and readiness to participate in anti-corruption reforms. Accordingly, the most informative for the purposes of our research was often not just what the participants in the focus groups said, but how they spoke, what associations they used, and how they positioned themselves in relation to the authorities in their narratives.

1. The level of trust in the state is one of the determining factors of political will. In the context of low trust in the state, public disappointment (which dominated in all focus groups) is converted into political apathy rather than into bottom-up pressure stimulating political will ${ }^{7}$. In a best case scenario, it is expressed by blaming particular politicians for the economic hardships, which reflects the clientelistic political culture more than bottom-up pressure on state institutions.

All focus groups demonstrate a generally low level of trust towards the state as well as towards the elected top-level politicians. The Euromaidan, unlike the Orange Revolution, involved not only representatives of organized civil society, but wider circles of ordinary people (Onuch, 2015). These people supported the revolution because they began to believe in the possibility of change, and expected these improvements in their lives immediately after the transition in the government. For these supporters, the lack of changes is especially painful:

During the Maidan, we believed strongly, we had strong faith, but now, as more time goes by, we no longer have faith in our authorities. (Galina 1, 53-60, Korostyshev ${ }^{8}$ ).

The growing disappointment with the outcomes of the revolution is converted into mistrust of the new political leadership: "we do not believe in the government, do not believe that we can change something" (Aleksey, 35-40 Kyiv). "People no longer believe. I think that they do not believe or have trust in anyone. (Natalia, 25-45, Korostyshev).

One of the biggest disappointments undermining belief in the possibility of change is that the "same people are still in power." People do not see any dif-

\footnotetext{
For a discussion of whether trust or distrust leads to political participation, see (Levy \& Stoker, 2000, pp. 486-488).

8 Here and further, the quotations are given in italic; the name of the narrator, the age interval of the focus group participants, and the city where the focus group was conducted are indicated in the brackets following the quotations.
} 
ference between the previous regime and the new political leadership ("I do not see any differences between the regime that left and the one in place now" Roman, 18-20, L'viv).

The popular assessment of Ukraine's political leadership is strongly negative in each city. One cannot find a single positive narrative in any focus group discussion. People in power are generally seen as time-servers who came into power with the sole purpose "to fill their pockets." The most critical of the political leaders are people in Kyiv and especially the young generation:

There is a mafia structure in power, unfortunately... There is a feeling that people there are constantly making money ... but in fact nothing is resolved and they accomplish nothing (Yevgenny 21-30 Kyiv).

I have the feeling that those who were in power were full. Now they have been replaced by people who are hungrier and more evil and they simply fill their bags. That is all. (Irina, 30-45, Kyiv).

Overall, the general common opinion can be summarized in the following quotation: "It looks like we have elected the wrong people" (Yurii 30-45, L'viv).

There is a threat that people are already getting so tired of the chaos and uncertainty that they would prefer to give up all together on political will and transfer all decision-making power to a totalitarian leader:

It is possible to elect a good leader who will be a tyrant and take everything in his fist; then there will not be a bunch of various others... (Dmitry 1) 18-20 Kharkiv).

2. Against the general background of complaints and curses, which characterized perceptions of the authorities usually from a clientelistic position, an interesting exception came in the calls for the need to carry out lustration. In contrast to the complaints and lamentations, the theme of the incomplete (and unstarted) lustrations rang out more like a demand which characterized a patron-oriented position. Against the background of general mistrust in the possibility for successful anti-corruption efforts undertaken by the corrupt state, the strong demand for a process of lustration and the punishment of corrupt officials and politicians does not look surprising. Typically, ordinary citizens do not distinguish between lustration and prosecution and use these terms as interchangeable notions. The necessity to replace corrupt politicians and officials at the top level was articulated in every focus group discussion by the people themselves (without any encouragement or special questions from the moderator). The idea of lustration as such is cheered by representatives of all regions and age groups, however everybody is disappointed by the incoherency and poor mechanisms for the practical implementation of the lustration law. The people are especially outraged by preservation of an "untouchable caste" among the top-level officials. Participants express the feeling that despite lustration, the same officials are returning to the positions they held before the revolution:

We should carry out lustration as a top priority (Korostyshev 53-65).

There have been no important cases, no one was jailed, no one was put on trial, they did not catch anyone, no one was indicted (Vladimir 46-60 Kharkov). 
Lustration is taking place at the lowest levels... while high level bureaucrats [are not touched]. Take our deputies, Yatsenyuk and all the rest. They have so many apartments (Aleksandr 25-45, Korostyshev).

On one hand, our leaders say that we should lustrate everyone who came to power under Yanukovych. On the other hand, there is no mechanism ... I think that lustration will not go all the way. Or it will be taken to absurd levels so that they can manipulate it. Or somehow achieve their interests. (Igor, L'viv 21-29).

The same old people return on the sly, that is, without explaining what is going on, they return to the same position or take another position, without advertising it (Sergei Kyiv 21-29).

The only positive aspect in trust to the state is that despite the general disappointment in the new political leadership, the dominating perception is that the country is headed in the right direction, even if the quality and pace of changes after Euromaidan are insufficient ("in general, the course is correct"). The assessments vary across region and generation. The most optimistic views are expressed by the citizens of L'viv: "I think that we are headed in the right direction, but are moving very slowly, there are many obstacles, which block movement" (Natalia, 18-20, L'viv). The citizens of the small city of Korostyshev also evaluate the general direction of the development as good: "Little by little. With great strength. Little by little we are moving in the direction that we should be moving. There are many inadequacies, but I think that we are moving little by little" (Sergey, 53-60, Korostyshev). The most negative and even aggressive assessments of the country's development are in Kyiv ("we are going backward" - Tatiana, 21-29 Kyiv).

3. The way people evaluate changes in the economy and society after Euromaidan can be also quite informative about people's political roles. While in general the progress in the country's development after Euromaidan is evaluated as extremely negative in all focus groups, there are essential differences in the criteria that people use to assess the changes. The majority of the participants evaluate the country's progress mainly through the prism of everyday economic life and growing economic hardships. This type of narration was particularly typical for the older generation. They blame politicians for rising prices on gas, electricity, inflation and a variety of other products.

Unlike the older generation, young people evaluate changes primarily through the achievement of Euromaidan goals: integration into Europe, reduction of corruption, and making the state more transparent: "one of the causes of the Revolution of Dignity was to fight corruption. What happened was that the leadership changed but corruption remains. They say a lot in words, but the facts show something different" (Stepan Kyiv 18-20).

Although the assessments of the changes are negative from both points of view, young people demonstrate a more "patron-type" position, when they care about long-term political goals. Notably, young people also seem to be more prepared to suffer economic hardships in favor of long-term positive perspectives. Some express understanding that economic depression is a necessary stage of economic reforms: 
Each country that joined the EU recently went through this difficult step which Ukraine is going through now. Each country sacrificed something. That includes price increases for communal services and in general. Life becomes more expensive, but you do not receive a bigger salary ... this will continue for some time while the overall economic situation stabilizes. The same happened in Poland, our neighbor. They also faced a very complicated economic crisis when they joined the European Union. But they survived this and the standard of living grew. They live much better than we do. In order to accomplish something, it is necessary to take this step I think. Everyone should understand this. (Marjana L'viv 18-20).

4. The focus groups demonstrated changes in people's solidarity, which is important from the point of view of perceiving oneself as a political actor within society. We can assume that the more people feel solidarity with others, the higher their ability to influence the political establishment is. In all of the focus groups, participants mentioned the changes in social relationships and interactions among members of society. However, the assessments of changes are different in different parts of Ukraine. Thus, in all of the focus groups that were conducted in L'viv, people (especially young people) speak of the growing trust and consolidation among citizens after Euromaidan. They mention new positive trends in people's interactions, such as friendliness and openness to each other.

In Kharkiv, in contrast, the changes in social interactions were unanimously viewed as negative. The participants pointed to an emerging divide in people's consciousness in recent years "...Somehow relations between people have changed... a year ago there was a sort of solidarity among the people and it was palpable. Now people are divided with one person saying one thing and others saying something else" (Dmintry 18-20, Kharkiv). Today people are "afraid to openly express their opinions because they fear provoking conflicts" (Bogdan 18-20 Kharkiv). However even in Kharkiv, some people also see a growing solidarity among the population, such as e.g., the volunteer movement: "It is surprising. I never imagined such a thing. A volunteer movement." (Aleksandr, 45-50 Kharkov).

While the assessments of the level of solidarity differ across the regional dimension, there is a positive change in people's minds that was unanimously agreed upon by all participants regardless of their age or geographical location. Namely, there is a growing popular self-consciousness and understanding of the people's role in the country's development, which is considered by the informants to be a result (or "cumulative effect") of the two revolutions:

Looking back in retrospect, I can say the following: during the revolution of 2004, people got to know each other. They understood that they could unite somehow. In 2013-4 ... I can say that people, probably, understood what their goal is. They understood what they should strive for. (Vladimir, L'viv, 21-29).

5. Ability to change the authorities in the country. For the analysis of political will, one of the most important changes that occurred in people's minds after Euromaidan seems to be the understanding that they can change their political leadership: 
I think that, in principle, things have changed. People in our country became more aware. They ... began to fear less. They saw that ... with the change of the authorities it was possible to change something (Roksolana 18-20 L'viv). We consider this change in people's minds to be the most important factor of political will in terms of bottom-up pressure on politicians.

All in all, we can assume that although trust in the state is still low among Ukrainian citizens, there is a growing belief in the possibility of changing the state from below. This swelling sentiment provides a positive incentive in the development of political will. The focus group material demonstrates that people, and especially young people, are no longer satisfied with serving as a "business resource" and are beginning to acquire and internalize the role of "principal" in the "principal-agent" model of relationships with politicians.

Influence should be concentrated in the hands of ordinary people. I went to the authorities and calmly said "I have these problems - to quickly solve my problem." (Igor, L'viv 21-29).

"People are trying to take responsibility for themselves - finally they understand that people in power are just managers who were elected for a short time. (Roman Kharkov 21-29).

Before the revolution it seemed to me that the majority of Ukrainians either did not know or did not understand this [Power to the People]. Afterwards, this is exactly what changed; the majority of Ukrainians, of course, not all of them, began to understand these words. Authority should be with the people. Not with the president, not with the parliament, etc. (Roksolana 18-20 L'viv).

\section{Perception of anti-corruption reforms.}

Corruption is seen by all focus group participants as the second most important problem hindering the country's development after the war. In general, the anti-corruption reforms are considered by people mostly as "window dressing" - not a real fight against corruption. People do not see any serious or sincere desire among state leaders to get rid of it (In my opinion, this is only words, Irina Kyiv 30-45). The general feeling is that corruption remains the same and is even getting more widespread ("the situation with corruption has become even worse" (Yurii 30-45 L'viv); "I think that now corruption is stronger than it was," Valentina 45-60 Kharkov) "[Corruption] here is even evolving" (Olga 1 Kyiv, 21-29); "if you compare us with Russia, here everyone is on the take, whereas there it is only Putin" (Алина Kyiv 21-29).

Against the background of the overall negative assessment of the battle against corruption, important criteria for our analysis include how the population sees the nature of corruption - quotidian corruption, bribe-taking by bureaucrats, and high-level kleptocracy including the theft of state resources - and the extent to which people see the connection between corruption and the general economic development of the country ${ }^{9}$. Despite the limited opportunities afforded by the material, there are several interesting differences between social and regional groups. For example, while defining corruption (at the request of the focus group

\footnotetext{
For a discussion on the distinction between corruption and bribes, see (Philp \& David-Barrett, 2015).
} 
moderator), young Kyiv citizens demonstrated broader and more profound views of corruption and its destructive impact on the economy than their counterparts in other cities. Unlike participants from regions outside the capital who mostly reduced the definition of corruption to bribes paid to public institutions and officials, participants from Kyiv primarily spoke about high-level corruption associated with oligarchic kleptocracy (stealing from the state), nepotism, "mafia"-like structures, "the illegal turnover of resources", "lack of transparency", etc.

Another criteria denoting patron-oriented relations with anti-corruption reforms is the representation of one's own abilities in the struggle against corruption. Generally, people expect that it is the state which is supposed to fight corruption in the first place. The direct question, "Who should fight corruption?" in most focus groups gets the direct answer "The state." While most of the participants (especially young people) agree that people stimulate (petty) corruption themselves, the overwhelming opinion is that it is impossible to fight the "upper-level" corruption "from the bottom" unless it is addressed by the leadership from above. Nevertheless, practically all participants lacked an understanding that it was possible to exert pressure on the state and politicians through democratic procedures ("Why are we guilty that these oligarchs creep into the Verkhovna Rada?" (Leonid, 53-60, Korostyshev). People are poorly informed about the anti-corruption activities of civil society (which demonstrates yet again how NGOs are cut off from the population) and do not know about the possibilities for engaging in the activities of non-profit organizations. These characteristics can serve as indicators of weak political will and in particular "political can."

In answer to a direct question about their preparedness to personally participate in the battle against corruption, young people more often express a readiness to participate in the anti-corruption battle, but they do not understand what they are supposed to do in order to help. In other words, there is a desire, but no understanding of how to use the opportunities to influence the battle against corruption. They need leadership from the state but do not see any coherent strategy of reforms:

It seems to me that there is no elementary, banal, or I don't know, global development or direction in the country... They tell everyone to be normal. That is, don't follow a particular person, but be normal. But are there any criteria to be normal? How should one behave in our case? Everyone has his own opinion, we are all different people (Igor, L'viv 21-29).

The popular view among young people is that the best way to fight corruption is to do a "total reboot" of the state (Dmitrii 2, Kharkov 18-20).

The readiness to participate in fighting corruption among the general public is proved by the recent uptick in anti-corruption non-profit activism (Nashi groshi, etc). There is still considerable potential in people's readiness to support changes, which is especially strong among the younger generation.

7. People's criteria for assessing political leaders can also serve as indicators of political will. The assessment criteria for political will and expectations from the political leadership can be divided into two groups: those expressed from a "principal-perspective" and those from an "agent-perspective." For instance, people with an "agent perspective" would expect political leaders to use elections in order 
to reward their supporters. People working from a "principal perspective" would hold leaders accountable in a "policy-making sense" (Rose-Ackerman, 2004, p. 9) that goes beyond partisan attempts and means accountability to the public in setting policy. In general, principals should expect a well-functioning state that is accountable to their people. Unfortunately, the empirical limits of our study do not allow us to implement such an analysis here.

\section{Discussion}

This paper makes several theoretical and empirical contributions. The first theoretical contribution is the further development of the concept of political will as it is used in political science literature. Our argument is that political will is not something that is uniquely associated with the qualities of a country's top leader, as is frequently implied by assessments of anti-corruption efforts. We also reject the notion that political will reflects a leader's ability to go against his immediate short term interests in order to pursue a bigger vision of reform, given that rationally a leader is unlikely to do that (Geddes, 1996). To provide a more useful understanding of political will we argue that the concept should be understood within the context of the relationship between state and society. The nature of this relationship determines the extent of political will in a society. Moreover, the nature of the relationship is defined essentially by whether people feel that they can influence the authorities and exert pressure on them to implement anti-corruption reforms.

Second, this paper makes a methodological contribution by laying out a methodology for measuring political will both in quantitative and qualitative terms. We do this by examining the expectations people have for the new leadership. In particular, by asking: Do people think of themselves as patrons or as clients? What do people pay more attention to in their leaders? Do people use client-based criteria or patron-based criteria? (Client-type attitudes towards the political leaders focus on the goods and services the politicians can deliver; patron-type expectations emphasize the ability to carry out reforms that will improve people's lives or make visible changes at the top.) Following up on this type of analysis is a topic for further research.

Finally, by conducting a qualitative analysis, this paper uses the narratives of participants in focus groups to formulate empirical indicators which can be used to measure political will. Also, even though the set of questions for the focus groups was not designed to research political will, the data allows us to make some preliminary assumptions about the evolving contours of political will in Ukrainian society following the Euromaidan Revolution. The analysis suggests, in particular, that there is a generational divide in Ukraine and that there are changes taking place in the clientelistic culture among young people. The positive changes towards the "patron-oriented" position we describe here are more apparent among young people. Their attitudes are different from those of their older countrymen. Interestingly, evidence in Russia also suggests that young people hold outlooks that differ somewhat from the previous generation, but at the same time they are also generally willing to accept the regime (Mickiewicz, 2014). 
The negative tendencies are that trust in the Ukrainian state remains low among ordinary Ukrainians. Nothing has changed in this regard since Euromaidan. People have little regard for the anti-corruption efforts that have been carried out so far. Given the clientelistic environment in which they live, ordinary people assess anti-corruption reforms and institutional changes through their everyday life or clearly visible changes at the top, such as lustration or the establishment of a new traffic police force. They do not focus on long-term institutional changes.

We also found regional differences among the focus groups participants. Residents in the western part of the country are more optimistic about reform than those in the eastern regions. But the residents of Kyiv were by far the most cynical.

The limits of the qualitative approach do not allow us to draw more general conclusions, however, the analysis presented here clearly highlights a variety of changes in the political will among the population of Ukraine, which demand deeper research and explanation.

\section{REFERENCES}

1. Brinkerhoff, D.W. (2000). Assessing political will for anti-corruption efforts: an analytic framework. Public Administration and Development, vol. 20, no 3.

2. Bueno de Mesquita, B., Smith, A., Siverson, R., \& Morrow, J. (2003). The Logic of Political Survival. Cambridge, MA: MIT Press.

3. Building Political Will. Topic Guide. Compiled By The Anti-Corruption Helpdesk (2015). Transparancy International.

4. Geddes, B. (1996). Politician's Dilemma: Building State Capacity in Latin America. Berkeley: University of California Press.

5. Greene, S.A. (2014). Moscow in Movement: Power and Opposition in Putin's Russia. Stanford: Stanford University Press.

6. Hale, H.E. (2014). Patronal Politics: Eurasian Regime Dynamics in Comparative Perspective. New York: Cambridge University Press.

7. Hale, H.E. (2016). Constitutional Performance after Communism: Implications for Ukraine. (In: H.E. Hale \& R.W. Orttung (Eds.) Beyond the Euromaidan: Comparative Perspectives on Advancing Reform in Ukraine). Stanford: Stanford University Press, pp. 124-140. 
8. Johnston, M. (2014). Corruption, Contention, and Reform. Cambridge: Cambridge University Press.

9. Kuzio, T. (2015). Ukraine: Democratization, Corruption, and the New Russian Imperialism. Santa Barbara: Praeger.

10. Levy, M. \& Stoker, L. (2000). Political Trust and Trustworthiness. Annual Review of Political Science, no 3, 475-507.

11. Lutsevych, O. (2013). How to Finish a Revolution: Civil Society and Democracy in Georgia, Moldova and Ukraine. London: Chatham House.

12. Malena, C. (2009). Building Political Will for Participatory Governance: An Introduction. (In: C. Malena (Ed.) From Political Won't to Political Will: Building Support for Participatory Governance). Helsinki: Kumarian Press, pp. 3-29.

13. Mickiewicz, E. (2014). No Illusions: The Voices of Russia's Future Leaders. Oxford: Oxford University Press.

14. Migdal, J. (2001). State in Society: Studying How State and Societies Transform and Constitute One Another. Cambridge: Cambridge University Press.

15. Onuch, O. (2014). Who Were the Protesters? Journal of Democracy, vol. 25, no 3, pp. 44-51.

16. Onuch, O. (2015). The Maidan, Past and Present: Orange Revolution (2004) and the EuroMaidan (2013-2014). (In: D.R. Marples \& F.V. Mills (Eds.) Ukraine's Euromaidan. Stuttgart: Ibidem Press.

17. Persson, A., \& Sjöstedt, M. (2012). Responsive and Responsible Leaders: A Matter of Political Will? Perspectives on Politics, vol. 10, no 3, pp. 617-631.

18. Philp, M. \& David-Barrett, E. (2015). Realism about Political Corruption. Annual Review of Political Science, vol. 18, pp. 387-402.

19. Post, L.A., A.N.W, Raile \& Raile, E.D. (2010). Defining political will. Politics and Policy, vol. 38, no 4, pp. 653-676.

20. Rose-Ackerman, S. (2004). Public Participation in Consolidating Democracies: Hungary and Poland. (In: J. Kornai \& S. Rose-Ackerman (Eds.) Building a Trustworthy State in Post-Socialist Transition). New York: Palgrave Macmillan, pp. 9-29.

21. World Bank. (2012). Fighting Corruption in Public Services: Chronicling Georgia's Reforms. Washington, D.C.: World Bank.

22. Zelinska, O. (2015). Who Were the Protestors and What Did They Want? Contentious Politics of Local Maidan across Ukraine, 2013-2014. Demokratizatsiya: The Journal of Post-Soviet Democratization, vol. 23, no 4, pp. 379-400. 